\title{
FLUORIDE TOXICITY ON HUMAN HEALTH FROM WATER RESOURCES AVAILABLE AT GRANITE MINE IN BAGALKOT DISTRICT, KARNATAKA, INDIA.
}

\author{
S. M. Goankar ${ }^{1}$, M. B. Kalashetti ${ }^{2}$ and Basavaraj M. Kalshetty ${ }^{3, *}$ \\ ${ }^{1}$ Research Scholar, R \& D Centre, Bharathiar University, Coimbatore, Tamil Nadu, India. \\ ${ }^{2}$ Department of Chemistry, Karnataka University, Dharwad, Karnataka, India. \\ ${ }^{3}$ BLDE'S Science College, Jamkhandi, District Bagalkot, Karnataka, India. \\ *E-mail: drkalshetty@gmail.com
}

\begin{abstract}
Physico-Chemical analysis of ground water samples was carried out from 30 locations of Bagalkot district such as Hungund, Badami, Ron, Kustagi and Bagalkot taluks. The analysis of different parameters such as pH, EC, TDS, Cl, $\mathrm{SO}_{4}, \mathrm{NO}_{3}$ and Fluoride were carried out as per the standard methods. All the parameters studied were within the permissible limit except Fluoride content in few locations. The analyzed results indicate the Fluoride concentration in some sampling spots namely Herur, Kesarabhavi, Benekanadoni, Balakundi, and Husur of Hunagund Taluk. Maradi village, Budanagad locations of Badami Taluk. Hanumasagar, Hanumanal villages of Kustagi Taluk. Tulasigeri, Simikeri (Govt. Primary School Campus) of Bagalkot Taluk, were found above standards (WHO- 1.0 ppm to $1.5 \mathrm{ppm}$ ) probably due to seasonal variations and salt water contamination. Fluoride ion in water sources is known for both beneficial and detrimental effects on live stock. The higher concentration of Fluoride in ground water causes a disease called "Fluorosis". It is a slow, progressive, crippling malady, which affects every organ, tissue and cells in the body system and results in health complaints having overlapping manifestations with several other diseases like chronic dental and skeletal Fluorosis.

Keywords: fluoride toxicity, human health, granite mining, fluorosis effect on body organ, genetic material.
\end{abstract}

(C) RASĀYAN. All rights reserved

\section{INTRODUCTION}

Fluoride occurs in combined state, it is present naturally in almost all foods and beverages including water, but levels of which can vary widely. Fluoride in drinking water to adjust concentrations in between $0.8 \mathrm{ppm}$ to $1.0 \mathrm{ppm}$ for the beneficial effect of teeth decay prevention. The Fluoride accumulation of ground water varies according to the source of water, area with semi-arid, climate, crystalline rock and alkaline soils of the area. The types of rocks composition of the host rock that water flows through and amount of rain fall are mainly affected ${ }^{1}$. Fluoride is a geochemical contaminant and natural sources account for most of the Fluoride in surface and ground water ${ }^{2}$. Its concentration is dependent on solubility of Fluoride containing rocks.

Fluoride ion in drinking water is known for both beneficial and detrimental effects on health. World Health Organization and Indian council of Medical Research described the drinking water quality guidelines values for Fluoride is $1.5 \mathrm{ppm}$ (Guidelines for drinking water quality International Standards for drinking water ${ }^{3,4}$. Low content ratio of Fluoride provides protection against dental caries, especially in children. In India around 60 million people including children were severely affected by Fluorosis because of high consumption of Fluoride content ${ }^{5}$. Longer exposure to Fluoride leads to certain types of bone diseases, mottling of teeth-enamel, nervous and skeletal disorder ${ }^{6}$. It also adversely affects the foetal cerebral function and neurotransmitters ${ }^{7}$.

The number of people getting affected, meanwhile villages, blocks, districts and states endemic for Fluorosis have been steadily increasing ever since the disease was discovered in India during 1930s. The reason for the increase in the disease incidence and the sizeable number of locations being identified as endemic zones for Fluorosis is due to overgrowth of population, necessitating more and more water, 
resorting to the use of hand pump water, unawareness regarding the importance of checking water quality especially for Fluoride content and due to water shortage. The agencies responsible for water supply (Municipal authorities) resort to pumping water from open wells bore wells to overhead tanks or direct supply to residents, and invariably such water sources are not tested for Fluoride ${ }^{8}$.

Keeping in view of the above, the present investigation under taken to assess fluoride concentrations in water resources available around granite mining and various adverse effects on human health by estimating fluoride level in drinking water, identification of exact geographical locations which are having high concentration of fluoride in water, toxicity of fluoride due to the consumption of drinking water in the area of Bagalkot district of Karnataka state in India, especially in Hunagund, Ilakal, Badami and Bagalkot Taluk.

The main objectives of this research work was to investigate the various aspects of fluoride and its importance in human life, as well as fluorosis effect on young and old men and women alike. This investigation may help in bringing awareness about fluorosis diseases to the public residing in that affected area.

\section{Material and Methods}

\section{EXPERIMENTAL}

Water samples were collected from 30 locations from various villages in and around Bagalkot district. All the samples were stored at $25^{\circ} \mathrm{C}$ and analyzed by using a fluoride selective electrode (Thermo Scientific Arian, Combination Fluoride Electrode No. 9609 BNWP) as per the prescribed standard methods ${ }^{9,10}$. All the Physico-chemical parameters were measured in accordance with standard methods ${ }^{11,12}$. While collection of water samples, the temperature was recorded by $110^{\text {th }}$ thermometer. All the Chemicals and reagents such as sodium fluoride, zyrconyl chloride, 3-alizerin sulphuric acid, ammonium acetate and other compounds used were of analytical grade. Double distilled water was used for preparing the required reagents and solutions.

Nitrate present in the water resources was measured by ion selective electrode method using digital ion$\mathrm{pH}$ meter (Elico equipments pvt. Ltd., India) by taking known volume $(25 \mathrm{ml})$ of water sample in $100 \mathrm{ml}$ beaker and equal volume of buffer solution for total ionic strength adjustment was added and stirred for 1 minute. The electrode was immersed, recorded the readings when stable. $\mathrm{pH}, \mathrm{EC}$, TDS and other chemical parameters of water samples were also measured by electrode method. The chloride, alkalinity, total hardness, calcium, magnesium and sulphur in the form of sulphate were determined by titrimetric methods and turbidity methods ${ }^{13}$.

All the parameter values were recorded in Tables-1 to 5, in different three seasons-during 2014-2015. These values were compared with the drinking water standards (table 6) of Bureau of Indian standards and World Health Organization for evaluation of Physico-chemical parameters, Nitrate ions and fluoride concentration in the water samples of the different locations were measured.

\section{RESULTS AND DISCUSSION}

It was observed that the water table depth found approximately in between $8-10$ meters (in the selected locations based on the enquiry from the local people). All the 30 water samples being using for domestic purposes by the public were analyzed their quality parameters such as $\mathrm{pH}, \mathrm{EC}, \mathrm{TDS}, \mathrm{Cl}, \mathrm{SO}_{4}$, nitrate and fluoride concentrations of the selected villages such as Belakundi of Hunagund Taluk, where the drinking water is supplying by the municipal board or by punchayat committee, through the water storage tanks. In addition to this the public of this area is also depended upon bore wells. But, in all locations, the water resources contaminated with the maximum fluoride concentration was noticed throughout the monitoring periods.

\section{Temperature}

The temperature of water is an important parameter because it effects bio-chemical reactions in aquatic organisms; rise in temperature reduces the solubility and amplifies the tests and odors. Hence, during summer days, DO values of water slightly decreases, the temperature of water and DO values are quite related. If the temperature of water reaches to $28^{\circ} \mathrm{C}$ to $29^{\circ} \mathrm{C}$, the $\mathrm{CO}_{2}$ gas begins to dissolve in water. 
Hence, water turns to acidic and forms carbonic acid, as a result the $\mathrm{pH}$ of water changes. The alteration in $\mathrm{pH}$ of water is accompanied by change in other physicochemical aspects of the medium.

The study area of Hunagund and Ilakal is covered by granite. The area is semi-arid with subtropics climate conditions. The temperature varies in these locations $27.5^{\circ} \mathrm{C}$ to $29.8^{\circ} \mathrm{C}$. The temperature of water samples were collected from the residential colonies situated in Bagalkot, Badami, Kustagi, Koppal and Ron in all three seasons were ranges in between $27^{\circ} \mathrm{C}$ to $29.0^{\circ} \mathrm{C}$.

\section{pH (Power of Hydrogen)}

The $\mathrm{pH}$ is an important index of hydrogen ion activity and is resulting value of acid-base interaction of number of mineral and organic components in water. The $\mathrm{pH}$ is an important ecological factor used universally to express the intensity of acid and alkaline condition of the water samples. Most of the water samples in the present investigation were slightly alkaline in nature (pH 7.2 to 7.8) due to the presence of carbonates $\left[\mathrm{CO}_{3}\right]$ and bicarbonates $\left[\mathrm{HCO}_{3}\right]$. Thus the $\mathrm{pH}$ values determine the equilibrium between free $\mathrm{CO}_{2}, \mathrm{CO}_{3}$ and $\mathrm{HCO}_{3}$.

In the study locations like Cholachagudda village of Badami, Hanumanal and Hanumsagar villages of Kustagi, Kalliganur of Ron, the $\mathrm{pH}$ values of water samples ranges in between 6.8 to 7.1. Whereas the water samples collected from Belakundi, Herur and Benakanadoni of Hunagund, the $\mathrm{pH}$ values were found to be 8.1, 7.8 and 7.8 respectively. Hence, the water is alkaline in nature due to the presence of $\mathrm{CO}_{3}$ and $\mathrm{HCO}_{3}$. The $\mathrm{pH}$ values more than 7.0 in water samples reflect contamination of bases like sodium hydroxide and calcium hydroxide ${ }^{14,15}$. Nevertheless, no acidic water found around the granite mining.

\section{Electrical Conductivity (EC)}

It is an important parameter for determining the water quality for drinking and agricultural purposes. Many dissolved substances may produce an esthetically displeasing color, taste, odor and salinity conditions in water samples. It signifies the amount of total dissolved solids. The higher EC values in water samples indicate the presence of high amount of total inorganic substances in ionized state. EC value is always correlated with TDS found in water and EC is an indicator of degree of mineralization of water. In the present investigation the EC values ranged in between $0.746 \mathrm{~m}$ mhos $/ \mathrm{cm}$ to $2.961 \mathrm{~m}$ mhos $/ \mathrm{cm}$ in Hunagund locations of Bagalkot district, $1.460 \mathrm{~m}$ mhos $/ \mathrm{cm}$ to $1.882 \mathrm{~m} \mathrm{mhos} / \mathrm{cm}$ in Kustagi Taluk of Koppal district, $0.486 \mathrm{~m}$ mos/cm to $1.240 \mathrm{~m} \mathrm{mhos} / \mathrm{cm}$ found in the locations of Ron Taluk of Gadag district and EC values found in between $1.419 \mathrm{~m} \mathrm{mhos} / \mathrm{cm}$ to $1.747 \mathrm{~m}$ mhos/cm in Badami Taluk of Bagalkot district. Except Ron locations the EC values of all locations of water samples found slightly higher than the permissible limit $(1.4 \mathrm{~m} \mathrm{mhos} / \mathrm{cm})$ indicates the presence of maximum total dissolved solids in water samples of Hunagund, Kustagi and Badami taluks. Whereas the EC values of Ron taluk found within the legal limit prescribed by the international standards.

\section{Total Dissolved Solids (TDS)}

Total dissolved solids are one of the desirable parameters of water for drinking purpose. The TDS values of water samples were measured by using Elico TDS meter. TDS indicates the salinity behavior of ground water. Water containing more than $500 \mathrm{ppm}$ of TDS is not considered desirable for drinking water supplies, but in unavoidable cases $1500 \mathrm{ppm}$ is also allowed. In the present investigation the TDS values of Hunagund locations ranged in between $354 \mathrm{ppm}$ to $1524 \mathrm{ppm}$ the minimum TDS values found in the ground water of Hosur village, where as the maximum TDS values found in Herur village of the same Taluk. The TDS values $1127 \mathrm{ppm}, 1071 \mathrm{ppm}, 1081 \mathrm{ppm}$ and $1217 \mathrm{ppm}$ found in the bore well water samples of Chinnapur, Kesarabhavi, Mahanthpur and Tumba villages of Hunagund Taluk respectively, the water will give threat on the health of human and other beings. in case of Ron Taluk (Kuntoji, Gajendragad and Kalliganur villages) the TDS values of ground water samples found below the prescribed limits recommended by the WHO and ISI standards. TDS values in case Kustagi and Badami locations found slightly more than $500 \mathrm{ppm}$. People of this area are asked to use the water for drinking purposes after RO purifications. 


\section{Chloride (Cl)}

Chloride serves as an indicator of pollution by sewage and industrial effluents. Chloride occurs in all ground waters, but in widely varying concentrations. Excessive chloride in potable water is not particularly harmful; however, chloride in excess (more than $250 \mathrm{ppm}$ ) imparts a salty taste to water. People accustomed to higher chloride in water are subjected to laxative effects. In the present investigation the chloride values ranged from $28.5 \mathrm{ppm}$ to $37.8 \mathrm{ppm}$ in the case of Kustagi Taluk of Koppal district. $26.6 \mathrm{ppm}$ to $35.6 \mathrm{ppm}$ found in Ron Taluk of Gadag district, and $27.6 \mathrm{ppm}$ to $36.9 \mathrm{ppm}$ from the water resources available in Badami Taluk of Bagalkot district. The maximum chloride concentration found in between $31.8 \mathrm{ppm}$ to $54.5 \mathrm{ppm}$ this is because of granite mines available around Hunagund Taluk of Bagalkot district.

\section{Sulphate $\left(\mathrm{SO}_{4}\right)$}

Sulphate in the water samples is depending upon the nature of the soils. Each and every water resources consist with sulphate in varying ranges. It is known that the sulphate concentration in water samples around $1000 \mathrm{ppm}$ has Laxative effect and causes gastrointestinal irritation. Excess sodium sulphate in water causes Cathartic action. The high concentration of $\mathrm{Na}$ and $\mathrm{MgSO}_{4}$ is associated with respiratory illness. In the present investigation sulphate concentration in Hunagund locations found in between 28.6 ppm $63.5 \mathrm{ppm}$ where as in Badami locations the sulphate concentration ranged in between $25.2 \mathrm{ppm}$ to $56.3 \mathrm{ppm}$. The higher concentration of sulphate in Hunagund area due to granite rocks, iron and manganese ores. The sulphate concentration in the study area of Kustagi, Ron and Badami found less than the prescribed legal limits (WHO: $150 \mathrm{ppm}$ to $250 \mathrm{ppm}$ ).

\section{Nitrate $\left(\mathrm{NO}_{3}\right)$}

The water samples having Nitrate concentration below $22.5 \mathrm{ppm}$ is said to be safe for agriculture uses, but higher than $22.5 \mathrm{ppm}$ showed increasing problems on food products and vegetations. Thus, water from various locations whose Nitrate concentrations more than $22.5 \mathrm{ppm}$ will be appeared to have gone in the increasing problem zone for agricultural purposes with regard to Nitrate concentrations. This is possibly due to unrestricted use of nitrogenous fertilizers in agricultural practices in the areas.

The analysis report reveals the Nitrate concentration is water samples collected from the locations of Hunagund of Bagalkot district found in between $14 \mathrm{ppm}$ to $21.3 \mathrm{ppm}$. Where as in the locations of Badami and Ron range in between $11 \mathrm{ppm}$ to $20.3 \mathrm{ppm}$ and $12.3 \mathrm{ppm}$ to $19.8 \mathrm{ppm}$ respectively. Kustagi Taluk of Koppal district found Nitrate ion concentration $102 \mathrm{ppm}$ to $18.9 \mathrm{ppm}$, all the vales were found within the prescribed legal limits.

\section{Fluoride (F)}

The major sources of Fluoride in ground water are fluoride bearing rocks such as fluorspar, Cryolite, Fluorspatite, granite rocks and hydroxyl apatite. Fluoride has widely been in the focus of public and scientific interest because of their important physiological role in the health of a man ${ }^{16}$. It is high time that an affordable solution should be found to minimize the fluoride contamination for maintaining the good health of the large population of the Hunagund, Ilakal, Bagalkot region of study area there is urgent need to carry out studies on hydro-chemical and hydro-geological aspect of occurrence of fluoride which can be useful to mitigate Fluorosis in the study area. Defluoridation tanks should also be installed in the villages which having high exposure of fluoride concentration in ground water resources where using for drinking purposes.

In the present investigation of water samples of Hunagund, Badami, Ilakal of Bagalkot district, Kustagi and Ron taluks in and around Bagalkot district out of 30 water samples 8 samples contained more Fluoride concentrations (above $2.4 \mathrm{ppm}$ ), the 7 water samples contained Fluoride concentration within the range of $1.5 \mathrm{ppm}$, and 4 water samples of study area consists with Fluoride concentration less than prescribed standard limit. The Fluoride concentration in the water samples of the villages such as Herur, Kesarabhavi, Benakanadoni Hosur and Balakundi of Hunagund taluk of Bagalkot district found in between $1.523 \mathrm{ppm}$ to $2.433 \mathrm{ppm}$ (Figures-1 and 3). Fluoride concentration in the ground water resources 
RASĀYAN J. Chem.

Vol. 10 | No. 1 |165-175 | January - March | 2017

of Hanumasagar, Hanamanal villages of Kustagi Taluk found in between $1.524 \mathrm{ppm}$ to $1.451 \mathrm{ppm}$ (Figure-4). The least Fluoride concentration fond in the ground water resources of Jalihal, Belur and Cholachagudda villages of Badami Taluk in the Bagalkot district (Figure-2).

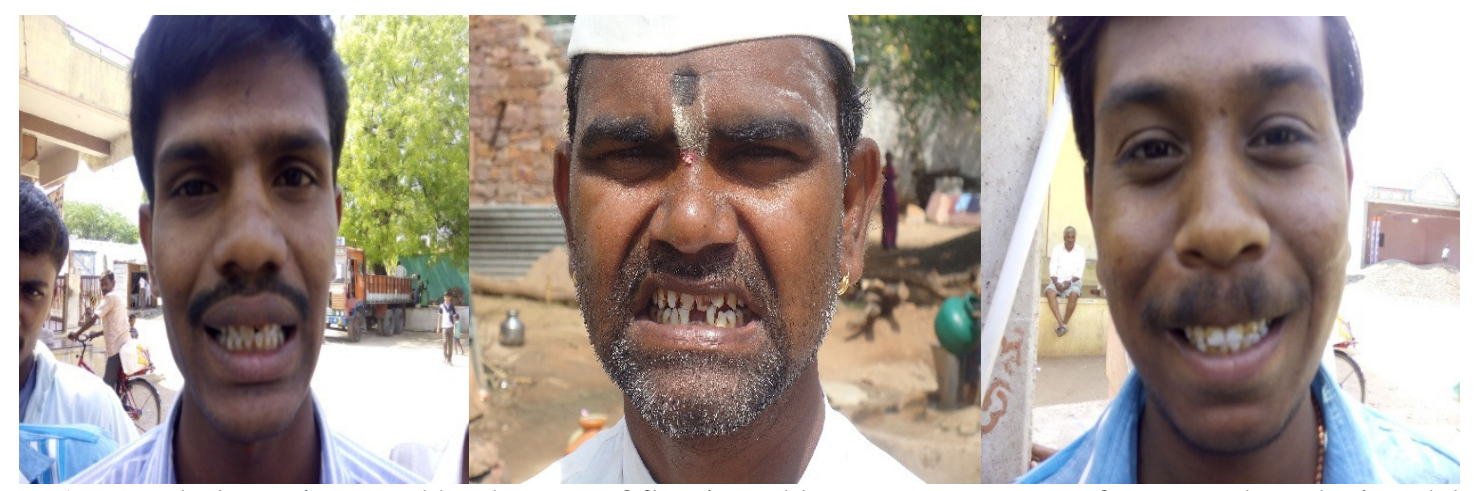

Picture-1: Dental Fluorosis caused by the uses of fluorinated bore water resources from Benakanadoni, Balakundi villages of Hunagund and Budangud village of Badami taluk.

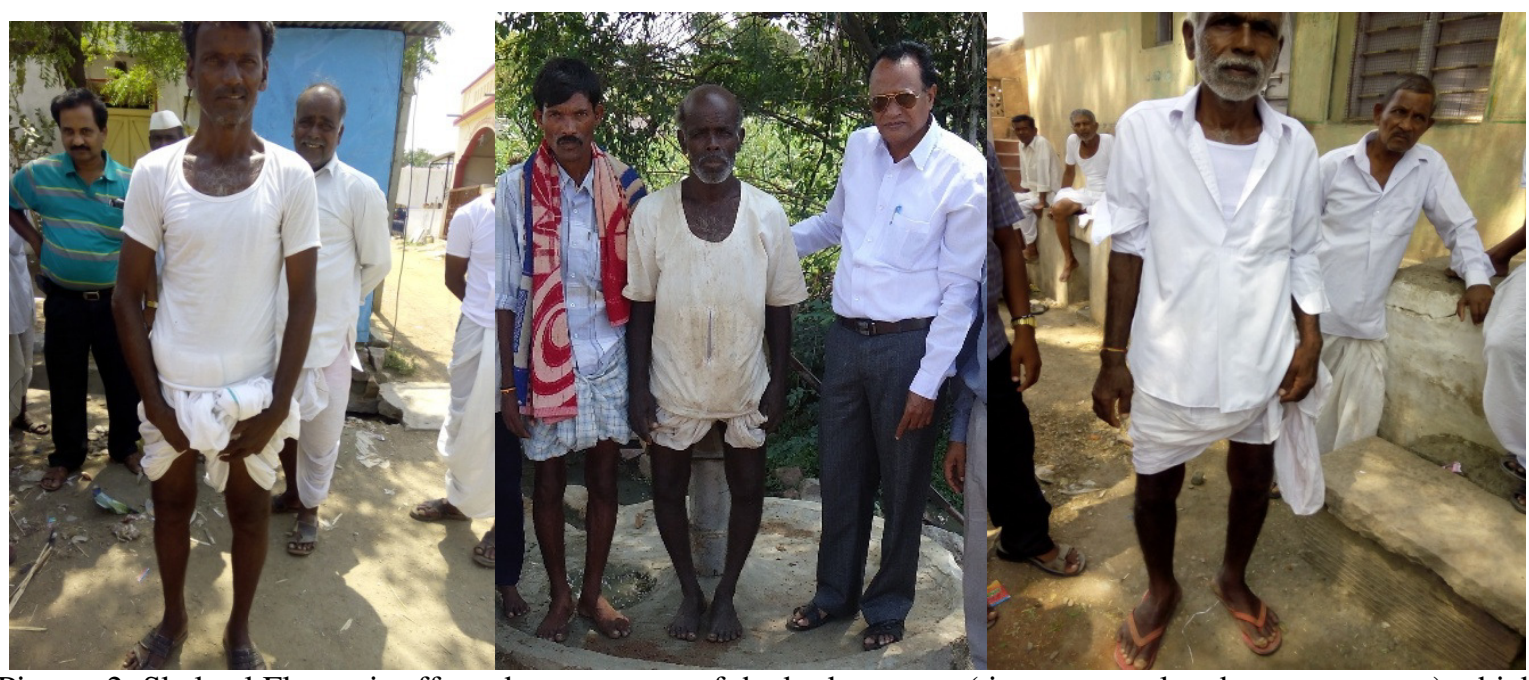

Picture-2: Skeletal Fluorosis affected every organ of the body system (tissue, mental and nerves system) which results in health complaints (Locations: Hosur, Yerigonal \& Kesarabhavi villages in and around Hunagund region).

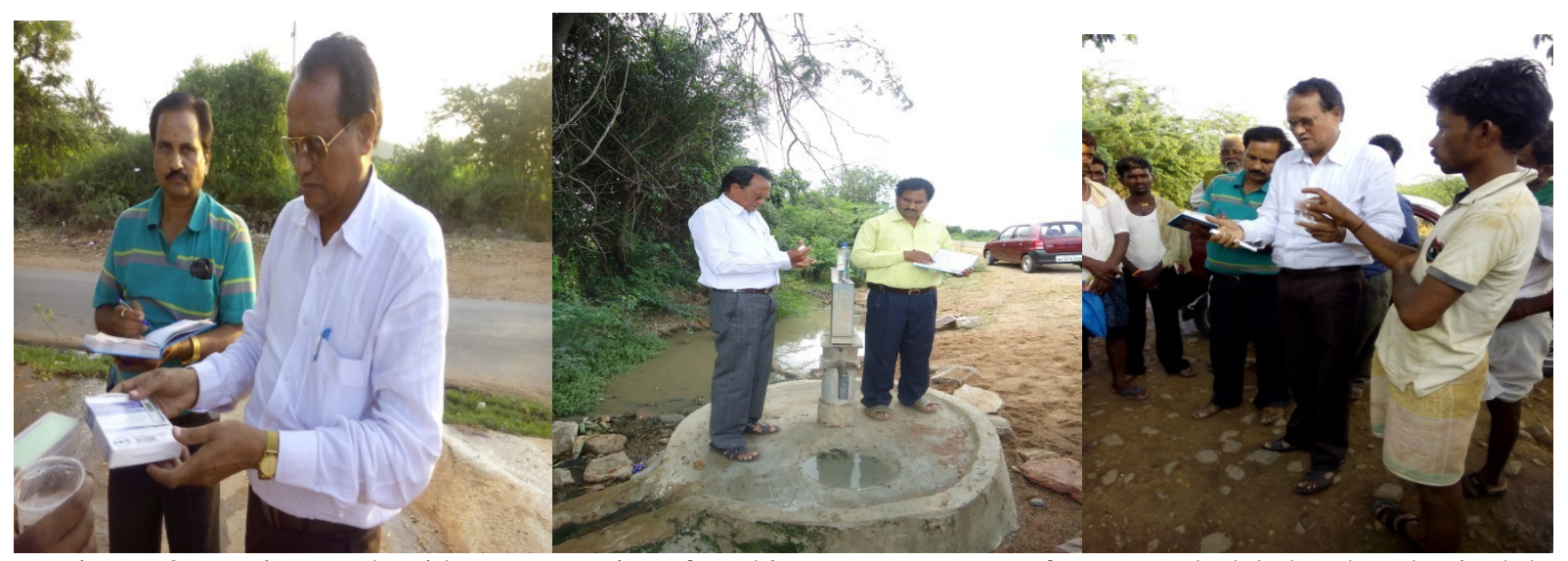

Picture-3: Maximum Fluoride concentrations found in water resources of Hunagund, Ilakal and Badami taluks (Bagalkot District) 
Higher concentration of Fluoride which is characterized by molting of teeth enamel, nervous and skeletal disorder (Picture-1 and 2). Ground water with high Fluoride content are generally Bicarbonates, sodium mixed water, particularly poor in Calcium content. Rocks which are rich in Fluoride mineral contributed enriched Fluoride contents of ground water. In the area of Bagalkot district the high levels of Fluoride are due to geogenic sources.

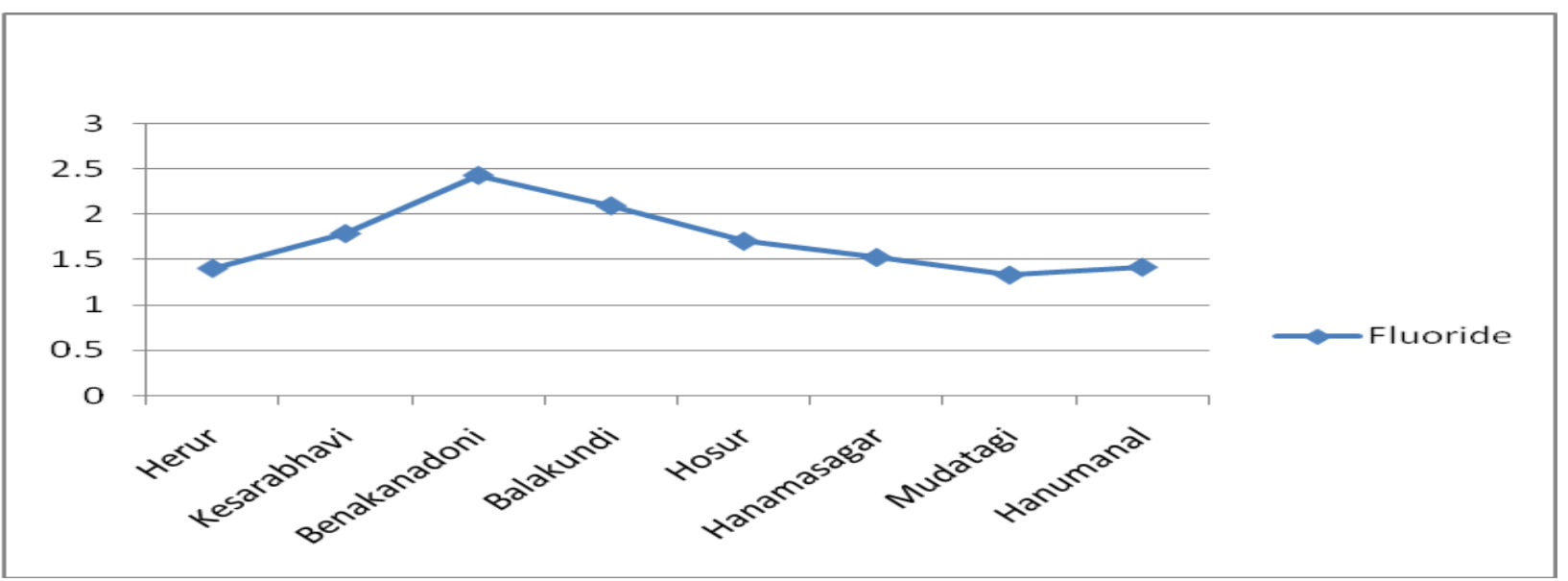

Fig.-1: Maximum fluoride content in Benakanadoni and Balakundi villages of Hunagund.

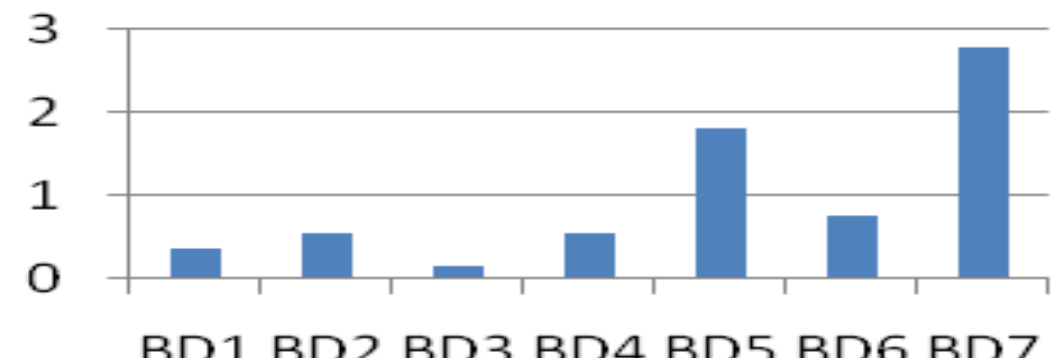

Fig.-2: Maximum fluoride content in Budangud village of Badami taluk. (Locations BD1 to BD7)

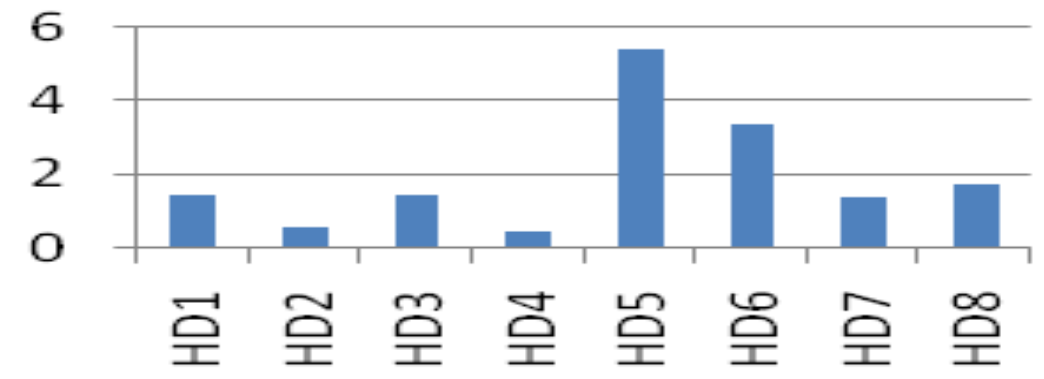

FLUORIDE

Fig.-3: Maximum fluoride content found in Yerigonal village in Hunagund region. (Locations HD1 to HD8) 


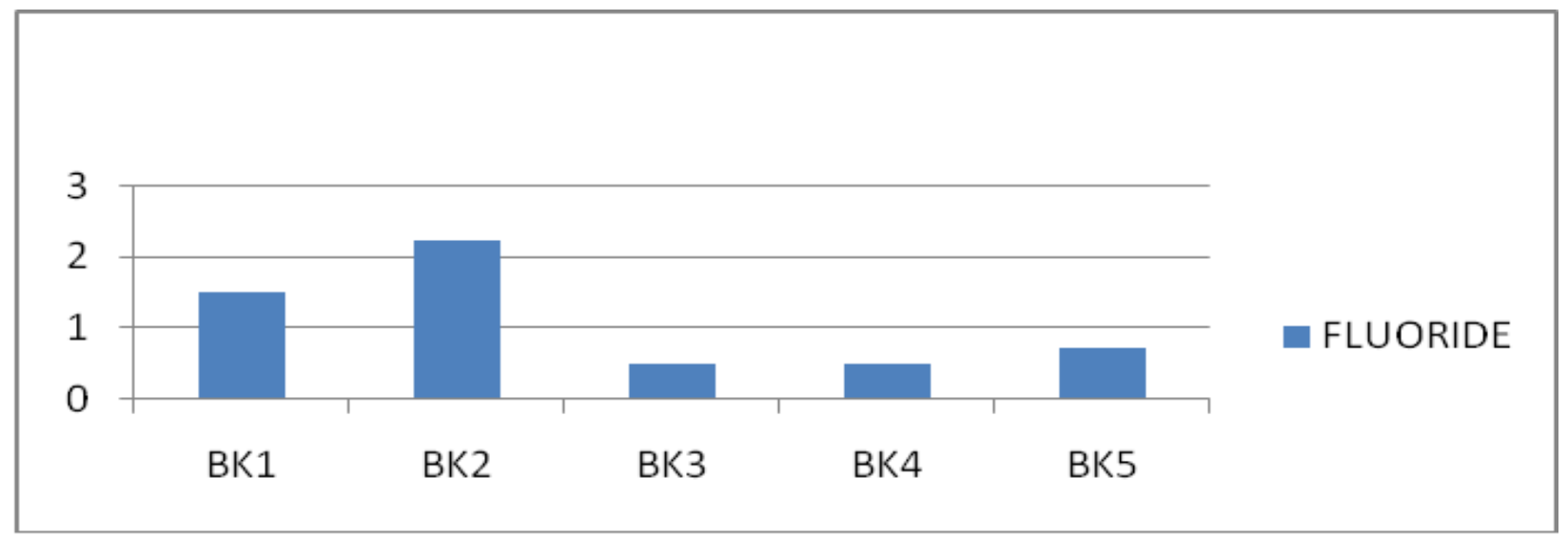

Fig.-4: Maximum Fluoride content found in ground water in Semikeri Village of Bagalkot District.

(Locations BK1 to BK5).

Regular intake of Fluoride enriched waters seems to be the main cause for Fluorosis in the study area (Picture-3). These will be helpful to prepare Fluorosis plan for the affected population of the study area. It should be better to Monitoring systems is to be established to periodically evaluate the prevalence of fluorosis and dental carries in the affected areas. Documents of water fluoride concentration may be kept in municipalities/punchayat for the benefit of public health providers, health professionals and the public with regard to fluoride consuming from drinking water.

Defluoridation tanks should also be installed in the villages like Kesabhavi ( $\mathrm{pH}$ 1.784), Benakadoni ( $\mathrm{pH}$ 2.433), Balakundi ( $\mathrm{pH} 2.096$ ) Hosur ( $\mathrm{pH} 1.703$ ) of Hunagund Taluk and Jalihal H.K. village (pH 1.572), and Belur ( $\mathrm{pH}$ 1.504) of Badami taluk. Around Bagalkot district some villages of Kustagi and Ron taluks are also affected by the kinds Fluorosis diseases, in these villages also having high exposure of Fluoride concentration in drinking water.

Table-1: Chemical parameters of water samples collected in and around Bagalkot district from the locations of Hunagund taluk during winter, summer and monsoon seasons of 2014-15

\begin{tabular}{c|c|c|c|c|c|c|c|c|c}
\hline S.No. & Village \& Taluk & Seasons & $\mathrm{pH}$ & $\begin{array}{c}\mathrm{EC} \mathrm{m} \\
\mathrm{mhos} / \mathrm{cm}\end{array}$ & $\begin{array}{c}\mathrm{TDS} \\
\mathrm{ppm}\end{array}$ & $\begin{array}{c}\mathrm{Cl} \\
\mathrm{ppm}\end{array}$ & $\begin{array}{c}\mathrm{SO}_{4} \\
\mathrm{ppm}\end{array}$ & $\begin{array}{c}\mathrm{NO}_{3} \\
\mathrm{ppm}\end{array}$ & $\begin{array}{c}\text { Fluoride } \\
\mathrm{ppm}\end{array}$ \\
\hline 1 & Herur of & Winter & 7.5 & 2.782 & 1296 & 30.2 & 27.8 & 17.3 & 1.503 \\
& Hunagund & Summer & 7.8 & 2.961 & 1396 & 31.8 & 28.6 & 18.6 & 1.523 \\
& & Monsoon & 7.4 & 0.746 & 1125 & 30.1 & $26 . .8$ & 17.8 & 1.421 \\
\hline 2 & Herur of & Winter & 7.2 & 2.864 & 1453 & 31.6 & 28.9 & 18.3 & 1.296 \\
& Hunagund & Summer & 7.2 & 2.961 & 1524 & 32.5 & 29.6 & 19.2 & 1.337 \\
& & Monsoon & 7.1 & 1.956 & 1123 & 32.0 & 27.6 & 19.0 & 1.293 \\
\hline 3 & Chinnapur & Winter & 7.1 & 2.143 & 1056 & 42.3 & 30.5 & 19.6 & 1.301 \\
& Hunagund & Summer & 7.3 & 2.244 & 1127 & 44.1 & 31.2 & 20.1 & 1.367 \\
& & Monsoon & 7.2 & 1.859 & 1005 & 41.3 & 31.0 & 18.9 & 1.323 \\
\hline 4 & Keasarabhavi & Winter & 7.6 & 2.048 & 1015 & 42.1 & 36.9 & 19.8 & 1.695 \\
& Hunagund & Summer & 7.8 & 2.150 & 1071 & 43.2 & 38.9 & 21.3 & 1.784 \\
& & Monsoon & 7.7 & 1.986 & 989 & 40.6 & 35.4 & 19.3 & 1.761 \\
\hline 5 & Mahantapur & Winter & 7.4 & 2.017 & 987 & 32. & 40.2 & 20.1 & 1.202 \\
& Hunagund & Summer & 7.5 & 2.149 & 1081 & 33.8 & 41.3 & 21.0 & 1.227 \\
& & Monsoon & 7.3 & 1.968 & 995 & 31.6 & 40.9 & 19.4 & 1.201 \\
\hline \multirow{3}{*}{5} & Tumba of & Winter & 7.2 & 2.147 & 1189 & 43.2 & 50.1 & 18.9 & 1.263 \\
& Hunagund & Summer & 7.3 & 2.396 & 1217 & 45.3 & 51.3 & 21.2 & 1.341 \\
& & Monsoon & 7.1 & 2.004 & 1025 & 44.3 & 50.6 & 19.3 & 1.306 \\
\hline 6 & Benakanadoni & Winter & 7.8 & 0.811 & 325 & 52.9 & 61.2 & 19.5 & 0.896 \\
& Hunagund & Summer & 8.1 & 0.812 & 394 & 54.5 & 63.5 & 21.3 & 0.923 \\
\hline
\end{tabular}


RASĀYAN J. Chem.

Vol. 10 | No. 1 |165-175 | January - March | 2017

\begin{tabular}{c|c|c|c|c|c|c|c|c|c}
\hline & & Monsoon & 7.6 & 0.789 & 301 & 52.6 & 62.6 & 20.3 & 0.854 \\
\hline 7 & Benakanadoni & Winter & 7.1 & 1.986 & 897 & 50.1 & 59.9 & 18.6 & 2.436 \\
& Hunagund & Summer & 7.8 & 2.028 & 996 & 53.2 & 62.5 & 19.2 & 2.443 \\
& & Monsoon & 7.5 & 1.895 & 852 & 51.2 & 61.5 & 17.8 & 2.430 \\
\hline 8 & Balakundi & Winter & 7.9 & 0.857 & 412 & 50.1 & 27.9 & 16.7 & 1.986 \\
& Hunagund & Summer & 8.1 & 0.874 & 418 & 52.6 & 29.1 & 18.8 & 2.096 \\
& & Monsoon & 8.0 & 0.789 & 396 & 51.6 & 28.9 & 15.8 & 1.963 \\
\hline 9 & Husur of & Winter & 7.5 & 0.698 & 325 & 43.2 & 29.5 & 16.5 & 1.639 \\
& Hunagund & Summer & 7.6 & 0.746 & 354 & 45.6 & 30.1 & 19.2 & 1.703 \\
& & Monsoon & 7.4 & 0.668 & 301 & 41.5 & 28.9 & 17.3 & 1.693 \\
\hline
\end{tabular}

Table-2: Chemical parameters of water samples collected in and around Bagalkot district from the locations of Badami taluk during winter, summer and monsoon seasons of 2014-15.

\begin{tabular}{c|c|c|c|c|c|c|c|c|c}
\hline S.No. & Village \& Taluk & Seasons & $\mathrm{pH}$ & $\begin{array}{c}\mathrm{EC} \mathrm{m} \\
\mathrm{mhos} / \mathrm{cm}\end{array}$ & $\begin{array}{c}\mathrm{TDS} \\
\mathrm{ppm}\end{array}$ & $\begin{array}{c}\mathrm{Cl} \\
\mathrm{ppm}\end{array}$ & $\begin{array}{c}\mathrm{SO}_{4} \\
\mathrm{ppm}\end{array}$ & $\begin{array}{c}\mathrm{NO}_{3} \\
\mathrm{ppm}\end{array}$ & $\begin{array}{c}\text { Fluoride } \\
\mathrm{ppm}\end{array}$ \\
\hline 1 & Jalihal H.K. & Winter & 7.5 & 1.321 & 789 & 25.6 & 24.6 & 10.6 & 1.153 \\
& Badami & Summer & 7.6 & 1.419 & 873 & 27.6 & 25.2 & 11.1 & 1.172 \\
& & Monsoon & 7.4 & 1.228 & 812 & 26.8 & 25.0 & 10.8 & 1.135 \\
\hline 2 & Belur of Badami & Winter & 7.2 & 1.536 & 698 & 33.2 & 45.3 & 14.6 & 1.210 \\
& & Summer & 7.3 & 1.652 & 717 & 34.2 & 46.8 & 15.9 & 1.304 \\
& & Monsoon & 7.2 & 1.455 & 696 & 33.9 & 45.9 & 14.6 & 1.223 \\
\hline 3 & Cholachagudda & Winter & 6.8 & 1.698 & 658 & 35.6 & 49.6 & 18.9 & 1.001 \\
& Badami & Summer & 6.8 & 1.747 & 700 & 36.5 & 56.3 & 20.3 & 1.109 \\
& & Monsoon & 6.7 & 1.692 & 698 & 36.1 & 48.7 & 19.2 & 1.086 \\
\hline 4 & Maradi Badami & Winter & 6.8 & 1.680 & 898 & 43 & 50 & 24 & 2.010 \\
& & Summer & 7.6 & 1.461 & 925 & 67 & 32 & 26 & 2.800 \\
& & Monsoon & 7.4 & 1.563 & 924 & 59 & 45 & 31 & 2.014 \\
\hline 5 & Budangad Badami & Winter & 7.3 & 1.620 & 900 & 98 & 68 & 15 & 2.29 \\
& & Summer & 7.5 & 1.610 & 900 & 95 & 54 & 18 & 2.80 \\
& & Monsoon & 7.4 & 1.598 & 895 & 92 & 42 & 16 & 2.65 \\
\hline \multirow{4}{*}{5} & Budangad Badami & Winter & 7.5 & 1.660 & 912 & 72 & 48 & 11 & 3.34 \\
& & Summer & 7.1 & 1.581 & 898 & 89 & 71 & 12 & 3.68 \\
& & Monsoon & & 1.485 & 852 & 78 & 56 & 12 & 3.58 \\
\hline 6 & Budangad Badami & Winter & 7.2 & 1.640 & 918 & 88 & 38 & 27 & 3.55 \\
& & Summer & 7.4 & 1.722 & 791 & 62 & 52 & 26 & 3.21 \\
& & Monsoon & 7.1 & 1.652 & 786 & 75 & 48 & 23 & 3.25 \\
\hline 7 & Agasanakoppa & Winter & 7.1 & 1.510 & 778 & 28 & 25 & 21 & 0.34 \\
& Badami & Summer & 7.2 & 1.520 & 820 & 38 & 33 & 23 & 0.48 \\
& & Monsoon & 7.3 & 1.598 & 789 & 35 & 35 & 22 & 0.52 \\
\hline 8 & Kerur of Badami & Winter & 7.1 & 1.98 & 842 & 101 & 78 & 27 & 0.72 \\
& & Summer & 7.0 & 1.95 & 821 & 82 & 62 & 23 & 0.53 \\
& & Monsoon & 7.2 & 1.85 & 824 & 95 & 80 & 25 & 0.65 \\
\hline & Guledagudda & Winter & 6.5 & 1.720 & 790 & 52 & 48 & 25 & 0.75 \\
& Badami & Summer & 6.9 & 1.642 & 798 & 110 & 40 & 22 & 0.82 \\
& & Monsoon & 6.8 & 1.689 & 769 & 85 & 51 & 20 & 0.85 \\
\hline
\end{tabular}

Table-3: Chemical parameters of water samples collected in and around Bagalkot district from the locations of Ron taluk during winter, summer and monsoon seasons of 2014-15.

\begin{tabular}{c|c|c|c|c|c|c|c|c|c}
\hline S.No. & Village \& Taluk & Seasons & $\mathrm{pH}$ & $\begin{array}{c}\mathrm{EC} \mathrm{m} \\
\mathrm{mhos} / \mathrm{cm}\end{array}$ & $\begin{array}{c}\mathrm{TDS} \\
\mathrm{ppm}\end{array}$ & $\begin{array}{c}\mathrm{Cl} \\
\mathrm{ppm}\end{array}$ & $\begin{array}{c}\mathrm{SO}_{4} \\
\mathrm{ppm}\end{array}$ & $\begin{array}{c}\mathrm{NO}_{3} \\
\mathrm{ppm}\end{array}$ & $\begin{array}{c}\text { Fluoride } \\
\mathrm{ppm}\end{array}$ \\
\hline 1 & Kuntoji of Ron & Winter & 7.3 & 0.412 & 212 & 26.3 & 44.5 & 11.2 & 1.336 \\
& & Summer & 7.4 & 0.486 & 228 & 26.6 & 45.6 & 12.0 & 1.377 \\
\hline
\end{tabular}


RASĀYAN J. Chem.

Vol. 10 | No. 1 |165-175 | January - March | 2017

\begin{tabular}{c|c|c|c|c|c|c|c|c|c}
\hline & & Monsoon & 7.2 & 0.458 & 213 & 25.6 & 43.2 & 11.6 & 1.320 \\
\hline 2 & Gajendragad & Winter & 7.3 & 1.012 & 265 & 30.2 & 65.2 & 12.6 & 1.303 \\
& Ron & Summer & 7.4 & 1.120 & 273 & 32.5 & 66.2 & 14.3 & 1.306 \\
& & Monsoon & 7.3 & 1.009 & 263 & 31.2 & 64.3 & 13.2 & 1.300 \\
\hline 3 & Kalliganur Ron & Winter & 6.9 & 1.158 & 501 & 34.2 & 73.2 & 19.5 & 1.396 \\
& & Summer & 7.0 & 1.240 & 598 & 35.6 & 72.6 & 20.1 & 1.422 \\
& & Monsoon & 6.8 & 1.198 & 512 & 33.6 & 71.5 & 18.6 & 1.402 \\
\hline
\end{tabular}

Table-4: Chemical parameters of water samples collected in and around Bagalkot district from the locations of Kustagi taluk during winter, summer and monsoon seasons of 2014-15.

\begin{tabular}{c|c|c|c|c|c|c|c|c|c}
\hline S.No. & Village \& Taluk & Seasons & $\mathrm{pH}$ & $\begin{array}{c}\mathrm{EC} \mathrm{m} \\
\mathrm{mhos} / \mathrm{cm}\end{array}$ & $\begin{array}{c}\mathrm{TDS} \\
\mathrm{ppm}\end{array}$ & $\begin{array}{c}\mathrm{Cl} \\
\mathrm{ppm}\end{array}$ & $\begin{array}{c}\mathrm{SO}_{4} \\
\mathrm{ppm}\end{array}$ & $\begin{array}{c}\mathrm{NO}_{3} \\
\mathrm{ppm}\end{array}$ & $\begin{array}{c}\text { Fluoride } \\
\text { ppm }\end{array}$ \\
\hline 1 & Mudatagi & Winter & 7.4 & $1 . .352$ & 659 & 27.8 & 59.6 & 19.9 & 1.320 \\
& Kustagi & Summer & 7.5 & 1.460 & 716 & 28.5 & 60.2 & 21.2 & 1.329 \\
& & Monsoon & 7.3 & 1.356 & 649 & 27.6 & 56.8 & 18.6 & 1.301 \\
\hline 2 & Hanamasagar & Winter & 6.9 & 1.742 & 8.95 & 29.6 & 69.7 & 18.4 & 1.522 \\
& Kustagi & Summer & 6.8 & 1.882 & 9.38 & 30.2 & 71.3 & 20.5 & 1.524 \\
& & Monsoon & 6.9 & 1.721 & 9.02 & 28.4 & 70.1 & 19.3 & 1.520 \\
\hline 3 & Hanamanal & Winter & 7.0 & 1.569 & 698 & 30.2 & 75.6 & 19.3 & 1.400 \\
& Kustagi & Summer & 7.1 & 1.622 & 797 & 34.5 & 82.3 & 22.0 & 1.416 \\
& & Monsoon & 7.0 & 1.581 & 712 & 31.2 & 79.2 & 20.4 & 1.410 \\
\hline 4 & Hanamanal & Winter & 7.3 & 1.269 & 612 & 36.4 & 88.6 & 15.6 & 1.449 \\
& Kustagi & Summer & 7.4 & 1.385 & 677 & 37.8 & 91.5 & 19.5 & 1.451 \\
& & Monsoon & 7.3 & 1.233 & 623 & 35.9 & 85.1 & 16.2 & 1.450 \\
\hline
\end{tabular}

Table-5: Chemical parameters of water samples collected in and around Bagalkot district from the locations of Bagalkot taluk during winter, summer and monsoon seasons of 2014-15.

\begin{tabular}{c|c|c|c|c|c|c|c|c|c}
\hline S. No. & $\begin{array}{c}\text { Village \& } \\
\text { Taluk }\end{array}$ & Seasons & $\mathrm{pH}$ & $\begin{array}{c}\mathrm{EC} \mathrm{m} \\
\mathrm{mhos} / \mathrm{cm}\end{array}$ & $\begin{array}{c}\mathrm{TDS} \\
\mathrm{ppm}\end{array}$ & $\begin{array}{c}\mathrm{Cl} \\
\mathrm{ppm}\end{array}$ & $\begin{array}{c}\mathrm{SO}_{4} \\
\mathrm{ppm}\end{array}$ & $\begin{array}{c}\mathrm{NO}_{3} \\
\mathrm{ppm}\end{array}$ & $\begin{array}{c}\text { Fluoride } \\
\mathrm{ppm}\end{array}$ \\
\hline 1 & Tulasigeri & Winter & 6.6 & 1.480 & 821 & 38 & 36 & 22 & 1.61 \\
& Bagalkot & Summer & 6.7 & 1.510 & 790 & 21 & 28 & 13 & 1.50 \\
& & Monsoon & 6.8 & 1.501 & 802 & 28 & 32 & 20 & 1.52 \\
\hline 2 & Semikeri & Winter & 6.7 & 1.518 & 792 & 69 & 43 & 36 & 2.32 \\
& Bagalkot & Summer & 6.6 & 1.683 & 786 & 52 & 36 & 21 & 2.23 \\
& & Monsoon & 6.8 & 1.568 & 768 & 47 & 50 & 29 & 2.30 \\
\hline 3 & Muchandi & Winter & 6.8 & 1.689 & 712 & 55 & 78 & 25 & 0.51 \\
& Bagalkot & Summer & 6.8 & 1.360 & 634 & 48 & 62 & 20 & 0.47 \\
& & Monsoon & 6.9 & 1.425 & 658 & 54 & 59 & 21 & 0.52 \\
\hline 4 & Sirur of & Winter & 6.9 & 1.368 & 798 & 54 & 38 & 21 & 0.49 \\
& Bagalkot & Summer & 6.7 & 1.570 & 723 & 36 & 42 & 18 & 0.48 \\
& & Monsoon & 6.9 & 1.512 & 734 & 42 & 39 & 16 & 0.50 \\
\hline 5 & Mannikeri & Winter & 6.7 & 1.720 & 698 & 78 & 71 & 24 & 0.78 \\
& Bagalkot & Summer & 6.9 & 1.710 & 634 & 61 & 61 & 19 & 0.72 \\
& & Monsoon & 6.8 & 1.698 & 686 & 72 & 70 & 22 & 0.80 \\
\hline
\end{tabular}

Table-6: Prescribed legal limits and guidelines

\begin{tabular}{c|c|c|c}
\hline Parameter & WHO & ISI & ICMR \\
\hline $\mathrm{pH}$ & $7.0-8.5$ & $6.5-8.5$ & $6.5-9.2$ \\
\hline EC & $1.4 \mathrm{ds} / \mathrm{m}$ & $1400 \mu \mathrm{s} / \mathrm{cm}$ & 250 \\
\hline TDS & 500 & 500 & $1500-3000$ \\
\hline BOD & 5.0 & 5.0 & --- \\
\hline COD & 10.0 & 10.0 & --- \\
\hline
\end{tabular}


RASĀYAN $J$. Chem.

Vol. 10 | No. 1 |165-175 | January - March | 2017

\begin{tabular}{c|c|c|c}
\hline DO & 5.0 & 5.0 & 5.0 \\
\hline Cl' & 250 & 250 & 1000 \\
\hline Calcium & $75-100$ & $45-75$ & 200 \\
\hline Magnesium & $30-150$ & 30 & 50 \\
\hline Sodium & 200 & 200 & --- \\
\hline Potassium & 1.4 & 1.4 & --- \\
\hline Sulphate & $150-250$ & $150-200$ & 400 \\
\hline TH & 300 & 300 & 600 \\
\hline TA & 120 & $200-600$ & $200-600$ \\
\hline Zinc & 0.75 & --- & --- \\
\hline Copper & 0.60 & --- & --- \\
\hline Iron & $<1$ & 0.3 & --- \\
\hline Manganese & 2.0 & 0.3 & --- \\
\hline Nitrate & $40-100$ & $40-100$ & $40-100$ \\
\hline Fluoride & $1.0-1.5$ & $1.0-1.5$ & $1.0-1.5$ \\
\hline Color & 5 HU & 5 HU & 5 HU \\
\hline Odor & Unobjectionable & Unobjectionable & Unobjectionable \\
\hline Turbidity & 5 NTU & 5 NTU & 5 NTU \\
\hline
\end{tabular}

\section{CONCLUSION}

The present study attempted to identify the areas affected by fluoride contamination in ground water resources of Bagalkot, Badami, Hungund and Ilakal taluks and around Bagalkot. The taluks like Kustagi of Koppal and Ron of Gadag districts were also affected by the fluoride contaminated ground water resources. The study has focused more on both urban and rural areas of Bagalkot district in order to supplement the data base in this direction. The following conclusions, recommendations and suggestions are made based on the investigation:

1. De-fluoridation tanks should be installed in such area having high concentration of fluoride in ground water resources.

2. Fluoride concentrations can be diluted by inducing ground water recharge techniques, i.e., construction of percolation tanks, flooding of ground water by mixing surface water by promoting rain water harvesting.

3. The financial support by the Government is made to install water purification units in the fluorosis affected area.

4. The possibilities of bringing safe water from nearby villages can also be planned by the municipal and punchayat authorities.

\section{ACKNOWLEDGEMENT}

Authors express their sincere thanks to Dr. C.N.R. Rao, FRS National Research Professor, Chairman Vision Group on Science and Technology, Bangalore. Authors also take this opportunity to extend their sincere gratitude to the Chairman and Coordinator of Research and Development Centre Bharathiar University Coimbatore. The authors are very thankful to Dr. B.G.Mulinami former vice-Chancellor and chief Administrative Officer, Vijaypur, Prof: S.H.Lagali Administrative Officer BLDE'S Association Vijaypur and Principal Dr. S. C. Hiremath for providing necessary facilities required to carry out this research work.

\section{REFERENCES}

1. S. Meenakhi, R.C. Maheswari, J. Hazard Mater., 137,456 (2006).

2. N.S. Rao, Goel. Soc. India, 40(5), 462(1992).

3. World Health Organization (1963), Guidelines for drinking water quality: International Standards for Drinking water, World Health Organization, $2^{\text {nd }}$ edition. 
4. Manual of Standards of Quality for Drinking Water Supplies (1975), Manual of Standards of Quality for Drinking Water Supplies, Special Report Series, Indian Council of Medical Research, $2^{\text {nd }}$ ed., p. 44.

5. D.S. Bendale, G.R. Choudhari, G.K. Gupta, Phys.Chem. Metallic Study Asian J. Chem. Environ., 3(1),65(2010).

6. A.K. Sushhela (2001), Treatise of fluorosis, Fluorosis Research in Rural Development Foundation, Delhi.

7. Y. Yu, W. Yang, Z. Dong (2000), Fluoride Research Report, p.33.

8. Treatise on Fuorosis, Fluorosis Research and Rural Development Foundation, Delhi, 2007.

9. Danesh Chand, J. Env. Prot., 19 (2), 81(1992),

10. E. Brown, M.W. Skougstad, M.J. Fishman, Washington DC: US Department of Interior,5, 60(1974).

11. Standard Methods for the Examination of Water and Waste Waters (1998), American Public Health Association, $20^{\text {th }}$ Ed., Washington, DC.

12. Sakuntala Chakrabarti and Pulak Kumar Patra, Rasayan J. Chem., 9(4), 627(2016).

13. T. Bhagya Kumar, O. Sailaja, K. Kiran Kumar and G. Krishnaveni, Rasayan J. Chem., 9(4), 858(2016).

14. D. Languir (1997), Aqueous Environmental Chemistry, Prentice - Hall Inc., New Jersey.

15. M.K. Basavaraj, S.M. Gaonkar, M.B. Kalashetti, S.S. Karabasannavar and R.S. Gani, Int. J Chem. Pharm. Sci., 2(5), 658(2014).

16. N.V. Ram Mohan Rao and K. Rajyalaxmi, Proceedings of the Symposium on Fluorosis. Hyderabad, 477 (1974).

[RJC-1596/2017] 